\title{
COVID-19 VACCINE HESITANCY AMONG HEALTH WORKERS IN SURGICAL DEPARTMENTS IN PORT HARCOURT, NIGERIA
}

\section{Promise N. Wichendu ${ }^{1}$, Rex Friday Ogoronte A. Ijah ${ }^{2 *}$ and Friday E. Aaron ${ }^{3}$}

${ }^{1}$ Department of Surgery, University of Port Harcourt Teaching Hospital, and Senior Lecturer, University of Port Harcourt, Port Harcourt, Nigeria.

${ }^{2}$ Department of Surgery, Rivers State University Teaching Hospital, Port Harcourt, and Lecturer, PAMO University of Medical Sciences, Port Harcourt, Nigeria.

${ }^{3}$ Consultant Orthopedic and Trauma Surgeon, Department of Surgery, Rivers State University of Port Harcourt Teaching Hospital, Port Harcourt, and Senior Lecturer, Rivers State University, Port Harcourt, Nigeria

*Corresponding Author Email: rexijah@gmail.com; Tel: +2348033953290

Cite this article:

Promise N.W., Rex F.O.A.I., Friday E.A. (2022), COVID19 Vaccine Hesitancy among Health Workers in Surgical Departments in Port Harcourt, Nigeria. African Journal of Biology and Medical Research 5(1), 17-29. DOI: 10.52589/AJBMRNYIEPRR0

\section{Manuscript History}

Received: 11 Jan 2022

Accepted: 31 Jan 2022

Published: 10 Feb 2022

Copyright $\odot 2022$ The Author(s). This is an Open Access article distributed under the terms of Creative Commons AttributionNonCommercial-NoDerivatives 4.0 International (CC BY-NC-ND 4.0), which permits anyone to share, use, reproduce and redistribute in any medium, provided the original author and source are credited.
ABSTRACT: Background: COVID-19 is a communicable respiratory tract disease caused by a new strain of coronavirus that causes disease in humans. Its status rose to that of a pandemic leading to many fatalities all over the world. Due to its devastation, COVID-19 vaccine production was fast tracked and granted emergency use authorisation. This process has evoked worldwide fears about its safety in the mind of the public, leading to vaccine uptake hesitancy even among healthcare workers. The aim of this study was to ascertain COVID-19 vaccine hesitancy among health workers in surgical departments of public tertiary healthcare facilities in Port Harcourt, Nigeria. Materials and Methods: A cross-sectional descriptive study was carried out among healthcare workers in public tertiary healthcare facilities. A total sample was aimed at administering questionnaires, and data was collated and analyzed using the Statistical Package for the Social Sciences (SPSS) version 20.0. Results: Two hundred and ninety-three (97.0\%) respondents were aware of COVID-19 vaccination of health workers and others in Port Harcourt, and only $161(53.3 \%)$ claimed to have taken the vaccine. To improve COVID-19 vaccination uptake rate, 133 (44.0\%) respondents suggested that the government should improve citizens' trust in them by being transparent and using traditional and religious leaders for public enlightenment $(23=7.6 \%)$, etc. Conclusion: There is significant COVID-19 vaccine hesitancy among workers in the surgical departments of the public tertiary hospitals in Port Harcourt, Nigeria. Lack of trust between the government and the citizens is a hindrance against COVID-19 vaccination.

KEYWORDS: COVID-19 Vaccine Hesitancy, Health Workers, Surgical Departments, Teaching Hospitals, Port Harcourt, Nigeria. 


\section{INTRODUCTION}

The coronavirus (COVID-19) pandemic has swept and is still sweeping through the world in its second wave, leaving behind unpleasant foot-prints of its passage. ${ }^{1-6}$ Continents, nations, communities and families have been hard-hit by the horror of this pandemic. ${ }^{7-12}$ Health professionals have also not been spared by the pandemic. ${ }^{13,14}$ Control measures have been advocated and implemented with some global benefits ${ }^{15}$ and challenges. ${ }^{16-18}$ Some positive impacts of the pandemic have also been reported, ${ }^{19-21}$ with notable long-lasting lifestyle changes. Business and educational activities during this pandemic have witnessed a boost in online audio and visual real-time meetings, teachings and conferences described as the new normal. $^{22,23}$

Studies have reported mutations and consequently many variants of COVID-19 virus in different countries over time, ${ }^{24-30}$ and in some cases different strains in the same country. ${ }^{31,32}$ The second and third waves of the COVID-19 virus infection have been reported in some countries ${ }^{33}$ with some reported to have increased virulence. ${ }^{34}$ Efforts have therefore been made in developing COVID-19 vaccines to mitigate the coronavirus pandemic. ${ }^{35-38}$ Some countries have started vaccinating their citizens with the COVID-19 vaccines, and some side effects have been reported following the use of some of the vaccines. ${ }^{39-41}$ Concerns have been raised about issues of misinformation particularly through the social media about coronavirus and its vaccine. ${ }^{42-46}$ This has unfortunately fueled skepticism about the vaccines' safety and consequently the acceptability.

When individuals display doubt about vaccine usefulness and safety, delay or outright refusal of acceptance, it is described as vaccine hesitancy. ${ }^{47-49}$ There are reported COVID-19 vaccine hesitancy described in some populations. ${ }^{50-54}$ In the Nigerian setting, there are deep-seated misconceptions, ${ }^{55-58}$ also fueled by religious beliefs. ${ }^{59,60}$ There is also the concern of public trust following some government postures on COVID-19 related issues. ${ }^{61,62}$ This study will evaluate the response of health workers in the surgical departments to the ongoing vaccination exercise with a view to ascertaining vaccine COVID-19 hesitancy, reasons for hesitancy, and what can be done to improve vaccination efforts among our people.

\section{MATERIALS AND METHODS}

A cross-sectional descriptive study was carried out among healthcare workers who were residents or practicing in Port Harcourt, the capital of Rivers State, being one of the Niger Delta states in the Federal Republic of Nigeria. The surgical departments of the two public tertiary healthcare facilities (teaching hospitals) were used as study sites. These teaching hospitals are multi-specialty centers that offer surgical services in general surgery, neurosurgery, otorhinolaryngologic surgery, dental/oral-maxillo-facial surgery, plastic surgery, cardiothoracic surgery, orthopedic surgery, obstetric and gynecologic surgery, urology, pediatric surgery, and laparoscopic surgery.

Semi-structured self-administered questionnaires were distributed to survey participants (all categories of health workers) aiming at a total sample. Information on socio-demographics, hesitancy among health workers, the proportion of COVID-19 vaccinated health workers, reasons for COVID-19 hesitancy, and suggestions on how to improve COVID-19 vaccination 
rate, were collated and analyzed using the Statistical Package for the Social Sciences (SPSS) version 20.0 .

\section{RESULTS}

A total of three hundred and two (302) respondents were recruited for the study. Three hundred and twenty questionnaires were distributed, and 302 were retrieved, giving a response rate of $94.4 \%$. The demographic characteristics of the respondents presented in Table 1 show that 165 $(54.6 \%)$ were males and $137(45.4 \%)$ were females. More than half $(56.3 \%)$ were between 25 and 40 years of age and only $6(2.0 \%)$ respondents were over 60 years old. 96 respondents $(31.8 \%)$ were single while $204(67.5 \%)$ were married. Ninety-nine respondents $(32.8 \%)$ had spent between six and ten years in service, while $6.3 \%$ had spent less than a year in service. Resident medical doctors were 105 (34.8\%), nurses were 55 (18.2\%), consultants were 51 (16.9\%), and administrative staff were 14 (4.6\%). One hundred and ninety-three (63.9\%) respondents were recruited from the University of Port Harcourt Teaching Hospital, while 109 (36.1\%) were from the Rivers State University Teaching Hospital.

Table 2 shows COVID-19 vaccination awareness and hesitancy among study participants. Two hundred and ninety-three (97.0\%) respondents were aware of COVID-19 vaccination of health workers and others in Port Harcourt, and only 161 (53.3\%) claimed to have taken the vaccine. Out of the $141(46.7 \%)$ who had not taken the vaccine, 24 (7.9\%) opined that they would never receive it, while $71(23.5 \%)$ were undecided. Out of the $24(7.9 \%)$ who never wanted to take the vaccine, $13(4.3 \%)$ claimed that the side effects of the vaccine were deadly and $9(3.0 \%)$ said the AstraZeneca brand in Nigeria was not genuine. One hundred and ninety-one $(63.2 \%)$ respondents were of the opinion that they would be willing to take the vaccine if it was made compulsory by their employer, while $44(14.6 \%)$ said they would never take the vaccine compulsorily but rather seek legal redress $(29=9.6 \%)$, resign $(6=2.0 \%)$, seek God's face $(11$ $=3.6 \%)$ or do nothing $(18=6.0 \%)$.

Table 1: Socio-demographic Characteristics of Respondents $(n=302)$

\begin{tabular}{lll}
\hline Variables & Frequency & Percentage \\
\hline Sex & & \\
Male & 165 & 54.6 \\
Female & 137 & 45.4 \\
Age & & \\
Less than 25 years & 14 & 4.6 \\
25 - 40 Years & 170 & 56.3 \\
41 - 60 years & 112 & 37.1 \\
More than 60 years & 6 & 2.0 \\
Marital Status & & \\
Single & 96 & 31.8 \\
Married & 204 & 67.5 \\
Divorced & 1 & .3 \\
Widowed & 1 & .3
\end{tabular}




\section{Religion}

Christianity

Islam

Others

$\begin{array}{ll}298 & 98.7 \\ 1 & .3 \\ 3 & 1.0\end{array}$

Number of Years in Service

Less than a year

1 - 5 years

6 - 10 years

$11-15$ years

16 - 20 years

More than 20 years

Category of respondents

Student (Undergraduate)

Consultant

Resident Doctor

13

Medical Officer

Pharmacist

26

Nurse

5

Medical Laboratory Scientist

Physiotherapist

3

Administrative Staff

3

Others

Optometrist

Institution of service

UPTH (Federal Teaching

Hospital)

RSUTH (State Teaching

Hospital)

109

36.1

Table 2: COVID-19 Vaccination Hesitancy Among Health Workers ( $(\mathbf{n}=302)$

\begin{tabular}{lll}
\hline Variables & Frequency & Percentage \\
\hline $\begin{array}{l}\text { Awareness of COVID-19 vaccination of health } \\
\text { workers and others in Port Harcourt }\end{array}$ & \\
Yes & 293 & 97.0 \\
No & 9 & 3.0 \\
Received COVID-19 vaccination & & \\
Yes & 161 & 53.3 \\
No & 141 & 46.7 \\
If "No", have intention of being vaccinated & & \\
Yes & 46 & 15.2 \\
Never & 24 & 7.9
\end{tabular}


African Journal of Biology and Medical Research

ISSN: 2689-534X

Volume 5, Issue 1, 2022 (pp. 17-29)

www.abjournals.org

May be

71

23.5

Received

161

53.3

Why never wanting to get vaccinated

The side effects are deadly 13

The AstraZeneca brand in Nigeria is not genuine

There is low risk of contracting the COVID-19

virus

It is related to antichrist/mark of the beast

.3

Received

None

Will take COVID-19 vaccine if made compulsory by employer

Yes

Never

May be

What to do if COVID-19 vaccine is made compulsory by employer

Nothing

Seek legal redress

Resign

Seek the face of God

To improve COVID-19 vaccination uptake rate (see Table 3), 133 (44.0\%) respondents suggested that the government should improve citizens' trust in them by being transparent. Other suggestions proffered include reduction of physical barriers to access the vaccine $(65=$ $21.5 \%)$, improvement in public enlightenment $(57=18.9 \%)$, use of traditional and religious leaders rather than politicians for enlightenment $(23=7.6 \%)$, etc. Besides, $91(43.0 \%)$ respondents were worried about the speed of the vaccine approval process, and $129(42.7 \%)$ expressed concern on safety of the vaccines used in Port Harcourt.

Table 3: Improving COVID-19 Vaccination Uptake Rate $(\mathbf{n}=302)$

\begin{tabular}{lll}
\hline Variables & Frequency & Percentage \\
\hline $\begin{array}{l}\text { Opinion on ways to improve COVID-19 vaccination } \\
\text { uptake rate }\end{array}$ & & \\
$\begin{array}{l}\text { Reduction of physical barriers to access the vaccine } \\
\text { Government should improve citizens' trust in them by }\end{array}$ & 65 & 21.5 \\
$\begin{array}{l}\text { being transparent } \\
\begin{array}{l}\text { Use traditional and religious leaders rather than } \\
\text { politicians for enlightenment }\end{array}\end{array}$ & 23 & 44.0 \\
\end{tabular}


African Journal of Biology and Medical Research

ISSN: 2689-534X

Volume 5, Issue 1, 2022 (pp. 17-29)

www.abjournals.org

Through improved public enlightenment

57

18.9

Government should make it compulsory

14

4.6

No opinion

10

3.3

Opinion on AstraZeneca vaccine use in Port

Harcourt

The efficacy is low

39

1.4

I have safety concerns about it

Worried about the speed of the vaccine approval process

91

43.0

No opinion

43

38.2

The relationship between age of respondents in years and acceptance of COVID-19 vaccination is presented in Table 4. It shows that the percentage of acceptance of COVID-19 vaccine increases with the age of the respondents. However, this relationship was not significant $(\mathrm{p}>0.05)$.

Table 4: Relationship Between Age of Respondents and Acceptance of COVID-19 Vaccination

\begin{tabular}{|c|c|c|c|c|c|}
\hline \multicolumn{6}{|c|}{ Received COVID-19 vaccination } \\
\hline $\begin{array}{l}\text { Age of respondents in } \\
\text { years } \\
\text { Less than } 25 \text { years }\end{array}$ & $\begin{array}{l}\text { Yes } \\
4(28.6 \%)\end{array}$ & $\begin{array}{l}\text { No } \\
10(71.49 \%)\end{array}$ & $\begin{array}{l}\text { Total } \\
14\end{array}$ & $\left(\mathrm{X}^{2}\right)$ & p-value \\
\hline $25-40$ Years & $89(52.4 \%)$ & $81(47.6 \%)$ & 170 & 4.596 & 0.204 \\
\hline $41-60$ years & $64(57.1 \%)$ & $48(42.9 \%)$ & 112 & & \\
\hline More than 60 years & $4(66.7 \%)$ & $2(33.3 \%)$ & 6 & & \\
\hline Total & 161 & 141 & 302 & & \\
\hline
\end{tabular}

The relationship between number of years in service and receiving COVID-19 vaccination is shown in Table 5. The proportion of those who had received the COVID-19 vaccine was highest among those who had spent more than 20 years in service compared to others and this relationship was statistically significant $(\mathrm{p}<0.05)$.

Table 5: Relationship Between Years in Service and Acceptance of COVID-19 Vaccination

\begin{tabular}{llllll}
\hline \multicolumn{5}{c}{ Received COVID-19 Vaccination } & \\
\hline Years in & Yes & No & Total & $\left(\mathbf{X}^{2}\right)$ & p-value \\
service/school & $4(21.1)$ & $15(78.9 \%)$ & $\mathbf{1 9}$ & & \\
Less than a year & $17(43.6 \%)$ & $22(56.4 \%)$ & $\mathbf{3 9}$ & & \\
1 - 5 years & $62(62.6 \%)$ & $37(37.4 \%)$ & $\mathbf{9 9}$ & \\
6 - 10 years & & &
\end{tabular}




\begin{tabular}{llclll}
$11-15$ years & $27(42.2 \%)$ & $37(57.8 \%)$ & $\mathbf{6 4}$ & & \\
$16-20$ years & $18(54.5 \%)$ & $15(45.5 \%)$ & $\mathbf{3 3}$ & 20.674 & $\mathbf{0 . 0 0 1}$ \\
More than 20 years & $33(68.8 \%)$ & $15(31.2 \%)$ & $\mathbf{4 8}$ & & \\
\hline Total & $\mathbf{1 6 1}$ & $\mathbf{1 4 1}$ & $\mathbf{3 0 2}$ & & \\
\hline
\end{tabular}

\section{DISCUSSION}

The demographics showed an almost equal number of respondents among the sexes, with a wide spread among categories of the workforce, showcasing the scope of coverage of the workers in the study. Majority of the respondents were of younger age (between 25 and 40 years) and married. Most respondents had spent at least 6 years in service in the surgical departments, with the majority working with the Federal Teaching Hospital. The teaching hospitals in the state are the places to find workers with the highest quality of knowledge about the ongoing coronavirus pandemic. The actions and opinions of the workers in the tertiary healthcare centres should provide a guide as to what the attitude of the workers in the primary and secondary healthcare centres would be. It should also act as a guide to the general public, most of whom are uninformed, and get their information largely from the unregulated social media. The findings of this study should therefore be an eye-opener to the realities of COVID19 vaccine hesitancy in the healthcare setting in Port Harcourt.

Almost all respondents were aware of the vaccination exercise for health workers for the COVID-19 pandemic, and only about half of the respondents had been vaccinated. It is curious to note that despite the almost $100 \%$ awareness, only about 50\% had received the vaccination after at least three months of the vaccination exercise by July 2021. The findings of hesitancy is similar to what was described among ethnic minorities in the United Kingdom, predominantly among blacks. ${ }^{51,63,64}$ The vaccine acceptance rate in our study is similar to reports from Italy, Russia, France, Poland and United States, but less than the values of over 90\% quoted for Ecuador, Malaysia, Indonesia and China. ${ }^{53}$ Although a small proportion of the health workers who had not received the vaccine were still insistent that they would never take the vaccine, it should be noted that most others were undecided. This implies that a pool of health workers was still tilted towards accepting the vaccines, with the right efforts. Also, the majority were willing to accept the vaccination under employer compulsion, while a few opted for resignation and legal redress. Civil societies and trade unions have expressed opinions against coercion for COVID-19 vaccination in England; however, a subtle implementation of policy has been reported to have been carried out. ${ }^{65}$ Misinformation has been reported as a key factor in lowering the acceptance of COVID-19 vaccine. ${ }^{66}$

The need for the government to improve citizens' trust by being transparent in dealing with COVID-19 issues was emphasized by the majority of respondents as a significant measure to improve vaccination uptake rate. This finding of our study is similar to reports elsewhere as COVID-19 pandemic is one disease in human history, among others, that has evoked sentiments and trust issues among the public in most societies. ${ }^{67-73}$ Reduction of physical barriers to access the vaccine, improvement in public enlightenment, and use of traditional and religious leaders rather than politicians for enlightenment were some of the measures advocated 
by respondents to improve COVID-19 vaccine uptake. The use of religious leaders/organizations in advocacy or enlightenment of the public has been recommended in other climes. ${ }^{67,74}$

Although there is no statistically significant relationship between age and acceptance of COVID-19 vaccination, our study shows that the older the respondent, the more likely they are to accept the vaccine. The finding of our study was relatively similar to that reported in other studies where older individuals had higher acceptance rate compared to the younger population. ${ }^{36,75}$ A likely explanation for this finding could be the risk of higher morbidity and mortality described among people of older age group who naturally are more likely to have comorbidities than the younger population. This fear is real as the unvaccinated have been reported to have seventeen times higher chances of being hospitalised due to COVID-19 virus infection. ${ }^{76}$ In another study, complete vaccination and younger age were associated with the likelihood for survival. ${ }^{77}$ Additionally, our study shows that respondents who had spent more years in the health service were more inclined to take the vaccine, as evidenced by a statistically significant relationship between acceptance of COVID-19 vaccine and working more than 20 years in service, compare to others. It stands to reason here that persons who have spent more than 20 years in the health service are more likely to belong to the older population.

\section{CONCLUSION}

The awareness of health workers on COVID-19 vaccination was high but the acceptance rate was not optimal. There is significant COVID-19 vaccine hesitancy among workers in the surgical departments of the public teaching hospitals in Port Harcourt, Nigeria. The foremost reason responsible for this finding is the lack of trust that exists between the government and the citizens in terms of the way policies on COVID-19 issue have been handled so far. Vaccine acceptance rate was higher among individuals who have been in the health service for twenty years or more.

\section{RECOMMENDATION}

A large pool of health workers was still undecided on whether to accept the vaccine or not. This population could be targeted with the right information to improve acceptance rate. Traditional institutions and religious leaders are recognized potential agents of change recommended for use in improving COVID-19 acceptance rate. The federal and state governments should review their relationship with the public with a view to improving trust among members of the public on COVID-19 issues.

\section{Footnote}

Acknowledgement: We acknowledge the staff of the surgical departments of the University of Port Harcourt Teaching Hospital and the Rivers State University Teaching Hospital for their cooperation/consent in sample collection for the study.

Ethical Considerations: The approval of the Research Ethics Committee of the two teaching hospitals was obtained before the commencement of the study. 
African Journal of Biology and Medical Research

ISSN: 2689-534X

Volume 5, Issue 1, 2022 (pp. 17-29)

www.abjournals.org

Funding: The study was privately sponsored by the researchers.

Conflict of Interest: None.

\section{REFERENCES}

[1]. Omer SB, Malani P, Del Rio C. The COVID-19 pandemic in the US: a clinical update. Jama. 2020;323(18):1767-8.

[2]. Decerf B, Ferreira FH, Mahler D, Sterck O. Lives and livelihoods: estimates of the global mortality and poverty effects of the Covid-19 pandemic. 2020.

[3]. Weinberger DM, Chen J, Cohen T, Crawford FW, Mostashari F, Olson D, et al. Estimation of excess deaths associated with the COVID-19 pandemic in the United States, March to May 2020. JAMA Internal Medicine. 2020;180(10):1336-44.

[4]. Sharma G, Volgman AS, Michos ED. Sex differences in mortality from COVID-19 pandemic: are men vulnerable and women protected? Case Reports. 2020;2(9):1407-10.

[5]. Peçanha T, Goessler KF, Roschel H, Gualano B. Social isolation during the COVID-19 pandemic can increase physical inactivity and the global burden of cardiovascular disease. American Journal of Physiology-Heart and Circulatory Physiology. 2020;318(6):H1441-H6.

[6]. Karlinsky A, Kobak D. The World Mortality Dataset: Tracking excess mortality across countries during the COVID-19 pandemic. medRxiv. 2021.

[7]. Boccia S, Ricciardi W, Ioannidis JP. What other countries can learn from Italy during the COVID-19 pandemic. JAMA internal medicine. 2020;180(7):927-8.

[8]. Power K. The COVID-19 pandemic has increased the care burden of women and families. Sustainability: Science, Practice and Policy. 2020;16(1):67-73.

[9]. Riley T, Sully E, Ahmed Z, Biddlecom A. Estimates of the potential impact of the COVID-19 pandemic on sexual and reproductive health in low-and middle-income countries. International Perspectives on Sexual and Reproductive Health. 2020;46:73-6.

[10]. Kraus S, Clauss T, Breier M, Gast J, Zardini A, Tiberius V. The economics of COVID19: initial empirical evidence on how family firms in five European countries cope with the corona crisis. International Journal of Entrepreneurial Behavior \& Research. 2020.

[11]. Fisher J, Languilaire J-C, Lawthom R, Nieuwenhuis R, Petts RJ, Runswick-Cole K, et al. Community, work, and family in times of COVID-19. Community, Work \& Family. 2020;23(3):247-52.

[12]. Bostan S, Erdem R, Öztürk YE, Kılıç T, Yılmaz A. The Effect of COVID-19 Pandemic on the Turkish Society. Electronic Journal of General Medicine. 2020;17(6).

[13]. Sethi BA, Sethi A, Ali S, Aamir HS. Impact of Coronavirus disease (COVID-19) pandemic on health professionals. Pakistan Journal of Medical Sciences. 2020;36(COVID19-S4):S6.

[14]. Temsah M-H, Al-Sohime F, Alamro N, Al-Eyadhy A, Al-Hasan K, Jamal A, et al. The psychological impact of COVID-19 pandemic on health care workers in a MERS-CoV endemic country. Journal of infection and public health. 2020;13(6):877-82.

[15]. Yoo S, Managi S. Global mortality benefits of COVID-19 action. Technological Forecasting and Social Change. 2020;160:120231.

[16]. Fitzgerald DA, Nunn K, Isaacs D. Consequences of physical distancing emanating from the COVID-19 pandemic: An Australian perspective. Paediatric respiratory reviews. 2020. 
[17]. Gabster BP, van Daalen K, Dhatt R, Barry M. Challenges for the female academic during the COVID-19 pandemic. The Lancet. 2020;395(10242):1968-70.

[18]. Ataguba JE. COVID-19 pandemic, a war to be won: understanding its economic implications for Africa. Springer; 2020.

[19]. Muhammad S, Long X, Salman M. COVID-19 pandemic and environmental pollution: A blessing in disguise? Science of the total environment. 2020;728:138820.

[20]. Ashraf BN. Economic impact of government interventions during the COVID-19 pandemic: International evidence from financial markets. Journal of behavioral and experimental finance. 2020;27:100371.

[21]. Cheval S, Mihai Adamescu C, Georgiadis T, Herrnegger M, Piticar A, Legates DR. Observed and Potential Impacts of the COVID-19 Pandemic on the Environment. International journal of environmental research and public health. 2020;17(11):4140.

[22]. Goh P-S, Sandars J. A vision of the use of technology in medical education after the COVID-19 pandemic. MedEdPublish. 2020;9.

[23]. Rajab MH, Gazal AM, Alkattan K. Challenges to online medical education during the COVID-19 pandemic. Cureus. 2020;12(7).

[24]. Eguia RT, Crawford KH, Stevens-Ayers T, Kelnhofer-Millevolte L, Greninger AL, Englund JA, et al. A human coronavirus evolves antigenically to escape antibody immunity. PLoS Pathogens. 2021;17(4):e1009453.

[25]. Dawood AA. Mutated COVID-19 may foretell a great risk for mankind in the future. New Microbes and New Infections. 2020;35:100673.

[26]. Nawaz MS, Fournier-Viger P, Shojaee A, Fujita H. Using artificial intelligence techniques for COVID-19 genome analysis. Applied Intelligence. 2021:1-18.

[27]. Tang JW, Tambyah PA, Hui DS. Emergence of a new SARS-CoV-2 variant in the UK. The Journal of infection. 2020.

[28]. Pathan RK, Biswas M, Khandaker MU. Time series prediction of COVID-19 by mutation rate analysis using recurrent neural network-based LSTM model. Chaos, Solitons \& Fractals. 2020;138:110018.

[29]. Maitra A, Sarkar MC, Raheja H, Biswas NK, Chakraborti S, Singh AK, et al. Mutations in SARS-CoV-2 viral RNA identified in Eastern India: Possible implications for the ongoing outbreak in India and impact on viral structure and host susceptibility. Journal of Biosciences. 2020;45(1):1-18.

[30]. Grabowski F, Preibisch G, Giziński S, Kochańczyk M, Lipniacki T. SARS-CoV-2 Variant of Concern 202012/01 has about twofold replicative advantage and acquires concerning mutations. Viruses. 2021;13(3):392.

[31]. Pachetti M, Marini B, Benedetti F, Giudici F, Mauro E, Storici P, et al. Emerging SARS-CoV-2 mutation hot spots include a novel RNA-dependent-RNA polymerase variant. Journal of translational medicine. 2020;18:1-9.

[32]. Otu A, Agogo E, Ebenso B. Africa needs more genome sequencing to tackle new variants of SARS-CoV-2. Nature Medicine. 2021:1-2.

[33]. Hibino S, Hayashida K, Ahn AC, Hayashida Y. COVID-19 seropositivity changes in asymptomatic individuals during the second and third waves of COVID-19 in Tokyo. medRxiv. 2021:2020.09. 21.20198796.

[34]. Al-Quwaie DA, Makki RM. Epidemiology and diagnostic tools of the new virulent pathogen of COVID-19: Case of Saudi Arabia. Arabia. 2020;16(4):21-32.

[35]. Le TT, Andreadakis Z, Kumar A, Román RG, Tollefsen S, Saville M, et al. The COVID-19 vaccine development landscape. Nat Rev Drug Discov. 2020;19(5):305-6. 
[36]. Lazarus JV, Ratzan SC, Palayew A, Gostin LO, Larson HJ, Rabin K, et al. A global survey of potential acceptance of a COVID-19 vaccine. Nature medicine. 2021;27(2):225-8.

[37]. Livingston EH. Necessity of 2 doses of the Pfizer and Moderna COVID-19 vaccines. JAMA. 2021;325(9):898-.

[38]. Calina D, Docea AO, Petrakis D, Egorov AM, Ishmukhametov AA, Gabibov AG, et al. Towards effective COVID-19 vaccines: Updates, perspectives and challenges. International journal of molecular medicine. 2020;46(1):3-16.

[39]. Blumenthal KG, Robinson LB, Camargo CA, Shenoy ES, Banerji A, Landman AB, et al. Acute Allergic Reactions to mRNA COVID-19 Vaccines. JAMA. 2021.

[40]. COVID C, Team R. Allergic reactions including anaphylaxis after receipt of the first dose of Moderna COVID-19 Vaccine-United States, December 21, 2020-January 10, 2021. Morbidity and Mortality Weekly Report. 2021;70(4):125.

[41]. Rutkowski K, Mirakian R, Till S, Rutkowski R, Wagner A. Adverse reactions to COVID-19 vaccines: a practical approach. Clinical \& Experimental Allergy. 2021.

[42]. Nguyen A, Catalan D. Digital mis/disinformation and public engagment with health and science controversies: fresh perspectives from Covid-19. Media and Communication. 2020;8(2):323-8.

[43]. Bertin P, Nera K, Delouvée S. Conspiracy beliefs, rejection of vaccination, and support for hydroxychloroquine: A conceptual replication-extension in the COVID-19 pandemic context. Frontiers in psychology. 2020;11:2471.

[44]. Liew CH, Flaherty GT. Immunity passports to travel during the COVID-19 pandemic: controversies and public health risks. Journal of Public Health. 2021;43(1):e135-e6.

[45]. Ahinkorah BO, Ameyaw EK, Hagan Jr JE, Seidu A-A, Schack T. Rising above misinformation or fake news in Africa: Another strategy to control COVID-19 spread. Frontiers in Communication. 2020;5:45.

[46]. Adekoya CO, Fasae JK. Social media and the spread of COVID-19 infodemic. Global Knowledge, Memory and Communication. 2021.

[47]. Dubé E, Gagnon D, MacDonald NE. Strategies intended to address vaccine hesitancy: Review of published reviews. Vaccine. 2015;33(34):4191-203.

[48]. Verger P, Dubé E. Restoring confidence in vaccines in the COVID-19 era. Taylor \& Francis; 2020.

[49]. Dubé E, Laberge C, Guay M, Bramadat P, Roy R, Bettinger JA. Vaccine hesitancy: an overview. Human vaccines \& immunotherapeutics. 2013;9(8):1763-73.

[50]. Grech V, Gauci C, Agius S. Vaccine hesitancy among Maltese healthcare workers toward influenza and novel COVID-19 vaccination. Early human development. 2020.

[51]. Razai MS, Osama T, McKechnie DG, Majeed A. Covid-19 vaccine hesitancy among ethnic minority groups. British Medical Journal Publishing Group; 2021.

[52]. Caspi G, Dayan A, Eshal Y, Taub SL, Twig G, Shalit U, et al. Socioeconomic disparities and COVID-19 vaccination acceptance: experience from Israel. medRxiv. 2021.

[53]. Sallam M. COVID-19 vaccine hesitancy worldwide: A concise systematic review of vaccine acceptance rates. Vaccines. 2021;9(2):160.

[54]. Troiano G, Nardi A. Vaccine hesitancy in the era of COVID-19. Public Health. 2021.

[55]. Izekor E, Okpuzor V, Morka E, Nnaji P. A Review of COVID-19 Pandemic: Myths, Misconceptions, and Role of Media Education in Nigeria. Asian Journal of Research in Infectious Diseases. 2020:10-9. 
[56]. Aminu J. The Implications of Misconceptions about Coronavirus Disease (COVID-19) Pandemic in Relation to its Daily Increases from Nigerian Perspective. J Infect Dis Epidemiol. 2020;6:156.

[57]. Omaka-Amari LN, Aleke CO, Obande-Ogbuinya NE, Ngwakwe PC, Nwankwo O, Afoke EN. Coronavirus (COVID-19) Pandemic in Nigeria: Preventive and Control Challenges within the First Two Months of Outbreak. African Journal of Reproductive Health. 2020;24(2):87-97.

[58]. Reuben RC, Danladi MM, Saleh DA, Ejembi PE. Knowledge, attitudes and practices towards COVID-19: an epidemiological survey in North-Central Nigeria. Journal of community health. 2020:1-14.

[59]. Ossai EC. 'It is the antichrist. Can't you see?'Perceptions of COVID-19 among Nigeria's Christians and the Religion-Health Debate. Studies in World Christianity. 2021;27(1):48-64.

[60]. Habib MA, Dayyab FM, Iliyasu G, Habib AG. Knowledge, attitude and practice survey of COVID-19 pandemic in Northern Nigeria. PloS one. 2021;16(1):e0245176.

[61]. Chukwuorji JC, Iorfa SK. Commentary on the coronavirus pandemic: Nigeria. Psychological Trauma: Theory, Research, Practice, and Policy. 2020;12(S1):S188.

[62]. Ilesanmi O, Afolabi A. Perception and practices during the COVID-19 pandemic in an urban community in Nigeria: a cross-sectional study. PeerJ. 2020;8:e10038.

[63]. Statistics OfN. Coronavirus and the social impacts on Great Britain: 29 January 2021. Office for National Statistics London; 2021.

[64]. Health RSoP. New poll finds BAME groups less likely to want COVID vaccine. 2020.

[65]. Hayes L, Pollock AM. Mandatory covid-19 vaccination for care home workers. British Medical Journal Publishing Group; 2021.

[66]. Loomba S, de Figueiredo A, Piatek SJ, de Graaf K, Larson HJ. Measuring the impact of COVID-19 vaccine misinformation on vaccination intent in the UK and USA. Nature human behaviour. 2021;5(3):337-48.

[67]. Gopez JMW. Building public trust in COVID-19 vaccines through the Catholic Church in the Philippines. Journal of Public Health. 2021;43(2):e330-e1.

[68]. Henderson J, Ward PR, Tonkin E, Meyer SB, Pillen H, McCullum D, et al. Developing and maintaining public trust during and post-COVID-19: can we apply a model developed for responding to food scares? Frontiers in Public Health. 2020;8:369.

[69]. Vergara RJD, Sarmiento PJD, Lagman JDN. Building public trust: a response to COVID-19 vaccine hesitancy predicament. Journal of Public Health. 2021;43(2):e291e2.

[70]. Schwartz JL. Evaluating and deploying COVID-19 vaccines-the importance of transparency, scientific integrity, and public trust. New England Journal of Medicine. 2020;383(18):1703-5.

[71]. Jakovljevic M, Bjedov S, Mustac F, Jakovljevic I. COVID-19 infodemic and public trust from the perspective of public and global mental health. Psychiatria Danubina. 2020;32(3-4):449-57.

[72]. Bekker M, Ivankovic D, Biermann O. Early lessons from COVID-19 response and shifts in authority: Public trust, policy legitimacy and political inclusion. European Journal of Public Health. 2020;30(5):854-5.

[73]. Gozgor G. Global evidence on the determinants of public trust in governments during the COVID-19. Applied research in quality of life. 2021:1-20. 
[74]. Organization WH. Behavioural considerations for acceptance and uptake of COVID-19 vaccines: WHO technical advisory group on behavioural insights and sciences for health, meeting report, 15 October 2020. 2020.

[75]. Nohl A, Afflerbach C, Lurz C, Brune B, Ohmann T, Weichert V, et al. Acceptance of COVID-19 Vaccination among Front-Line Health Care Workers: A Nationwide Survey of Emergency Medical Services Personnel from Germany. Vaccines. 2021;9(5):424.

[76]. Havers FP, Pham H, Taylor CA, Whitaker M, Patel K, Anglin O, et al. COVID-19associated hospitalizations among vaccinated and unvaccinated adults $\geq 18$ yearsCOVID-NET, 13 states, January 1-July 24, 2021. medRxiv. 2021.

[77]. Muthukrishnan J, Vardhan V, Mangalesh S, Koley M, Shankar S, Yadav AK, et al. Vaccination status and COVID-19 related mortality: A hospital based cross sectional study. medical journal armed forces india. 2021;77:S278-S82. 